\title{
Prevalence and risk factors for bovine brucellosis in the State of Santa Catarina, Brazil
}

\section{Prevalência e fatores de risco para brucelose bovina no estado de Santa Catarina, Brasil}

\author{
Karina Diniz Baumgarten ${ }^{1}$; Flávio Pereira Veloso ${ }^{1}$; José Henrique Hildebrand \\ Grisi-Filho²; Fernando Ferreira ${ }^{2}$; Marcos Amaku²; Ricardo Augusto Dias ${ }^{2}$; \\ Evelise Oliveira Telles ${ }^{2}$; Marcos Bryan Heinemann²; \\ Vitor Salvador Picão Gonçalves ${ }^{3}$; José Soares Ferreira Neto ${ }^{2 *}$
}

\begin{abstract}
A study was conducted to verify that the State of Santa Catarina has maintained a low prevalence of bovine brucellosis, which would allow the state to move forward with implementing strategies for disease eradication. The state was divided into five regions. In each region, a predetermined number of randomly selected properties was sampled. In each property, blood samples were collected from randomly selected cows with ages equal to or greater than 24 months. Sera from the animals were submitted to a serial testing protocol, with screening by the buffered acidified antigen test and confirmation by the 2-mercaptoethanol test. In each property, a questionnaire was used to identify the risk factors associated with the disease. In the state, the prevalence rate of infected herds was $0.912 \%$ [0.297 - 2.11] and infected animals was $1.21 \%$ [ $0.09-4.97]$. Relative to the earlier study in 2002 , there was no difference. The risk factors associated with the condition of a herd infected with brucellosis were as follows: herd size $\geq 12$ cows $(\mathrm{OR}=7.47[2.14-34.34])$ and the presence of flooded areas $(\mathrm{OR}=5.68[1.62-26.13])$. In view of the low prevalence, it is recommended that the state proceed with the implementation of eradication strategies that are based on a surveillance system structured to detect and eliminate infected herds, and supported by an effective compensation fund for the replacement of seropositive animals. Additionally, the State should make a significant effort to educate and supervise producers to ensure the testing of breeding animals for brucellosis before introducing them into their properties.

Key words: Brucellosis. Prevalence. Risk factors. Surveillance System. Santa Catarina. Brazil.
\end{abstract}

\section{Resumo}

Foi realizado um estudo para verificar se Santa Catarina continua com baixas prevalências de brucelose bovina, permitindo ao estado avançar de forma segura no seu projeto de implementação de estratégias de erradicação da doença. O estado foi divido em cinco regiões e em cada uma delas foi amostrado um número preestabelecido de propriedades, aleatoriamente selecionadas. Em cada propriedade foram colhidas amostras de sangue de fêmeas com idade igual ou superior a 24 meses, também selecionadas aleatoriamente. Os soros dos animais foram submetidos a um protocolo de testes em série, com triagem

${ }^{1}$ Médicos Veterinários, Companhia Integrada de Desenvolvimento Agrícola de Santa Catarina, CIDASC, Florianópolis, SC, Brasil. E-mail: kdiniz@cidasc.sc.gov.br, fveloso@cidasc.sc.gov.br

2 Profs., Faculdade de Medicina Veterinária e Zootecnia, Universidade de São Paulo, USP, São Paulo, SP, Brasil. E-mail: grisi@, vps.fmvz.usp.br; fernando@vps.fmvz.usp.br; amaku@vps.fmvz.usp.br; dias@vps.fmvz.usp.br; evelise@vps.fmvz.usp.br; marcosbryan@usp.br; jsoares@vps.fmvz.usp.br

${ }^{3}$ Prof., Faculdade de Agronomia e Medicina Veterinária, Universidade de Brasília, UNB, Brasília, DF, Brasil. E-mail: vitorspg@ unb.br

* Author for correspondence 
pelo teste com Antígeno Acidificado Tamponado e confirmação pelo 2-Mercaptoetanol. Em cada propriedade foi aplicado um questionário para individualizar os fatores de riscos associados à doença. No estado, a prevalência de focos foi $0,912 \%$ [0,44 - 1,67] e a de animais $1,21 \%$ [0,09 - 4,97], não havendo diferença em relação ao estudo anterior, realizado em 2002. Os fatores de risco associados à condição de foco de brucelose foram: o tamanho do rebanho $\geq 12$ fêmeas $(\mathrm{OR}=7,47[2,14-34,34])$ e a presença de áreas alagadiças $(\mathrm{OR}=5,68[1,62-26,13])$. Tendo em vista a baixa prevalência, recomenda-se que estado deve dar seguimento à implementação de estratégias de erradicação, baseadas na estruturação de sistema de vigilância para detecção e saneamento de focos, apoiado por eficiente fundo de indenização para a reposição de animais positivos aos testes sorológicos. Adicionalmente, o estado deveria realizar um grande esforço de educação e de fiscalização, para que os produtores testem os animais de reprodução para brucelose antes de introduzi-los em suas propriedades.

Palavras-chave: Brucelose. Prevalência. Fatores de risco. Sistema de vigilância. Santa Catarina. Brasil.

\section{Introduction}

Brucellosis, one of the most important infectious diseases worldwide, is caused by a Gramnegative bacterium of the genus Brucella. It is widely distributed, causes economic losses in the production of livestock, and is also considered the highest transmissible zoonosis by direct contact with infected animals or the consumption of infected milk and dairy products (ADONE; PASQUALI, 2013; SANTOS et al., 2013).

Among the 10 known species of Brucella, only four infect production animals and the most widespread worldwide is Brucella abortus (DÍAZ APARICIO, 2013; PAULIN; FERREIRA NETO, 2003), the infectious agent of bovine brucellosis.

In 2001, the Brazilian Ministry of Agriculture, Livestock and Supply (MAPA) launched the National Program for the Control and Eradication of Animal Brucellosis and Tuberculosis (PNCEBT) (LAGE, 2006), after which the Brazilian States conducted epidemiological studies to characterize bovine brucellosis, generating high quality information to support the choice of the best strategies to combat the disease. The results of these studies have shown a very heterogeneous situation among the States, with prevalence of herds infected with bovine brucellosis varying from $0.32 \%$ in the State of Santa Catarina to $41.5 \%$ in the State of Mato Grosso do Sul (SIKUSAWA et al., 2009; ALVES et al., 2009; AZEVEDO et al., 2009; CHATE et al., 2009; DIAS et al., 2009a, 2009b; GONÇALVES et al., 2009a, 2009b; KLEIN-GUNNEWIEK et al., 2009; MARVULO et al., 2009; OGATA et al., 2009; ROCHA et al., 2009; SILVA et al., 2009; VILLAR et al., 2009; NEGREIROS et al., 2009; BORBA et al., 2013; ALMEIDA et al., 2016; CLEMENTINO et al., 2016).

The States of São Paulo, Minas Gerais, Espírito Santo, Rondônia, Mato Grosso, Mato Grosso do Sul, and Rio Grande do Sul have conducted a second prevalence study of brucellosis to assess the effectiveness of their vaccination programs; however, a decrease in prevalence of infected herds was only confirmed in Mato Grosso, Mato Grosso do Sul, Minas Gerais and Rondônia (BARDDAL et al.; 2016; DIAS et al., 2016; ANZAI et al., 2016; INLAMEA et al., 2016; LEAL FILHO et al., 2016; OLIVEIRA et al., 2016; SILVA et al., 2016). The very low prevalence found in Santa Catarina led the MAPA to prohibit vaccination with the B19 strain in the state and encouraged it to build strategies for the eradication of the disease.

The State of Santa Catarina occupies only $1.12 \%$ of the national territories; however, its animal production is substantial, being the largest exporter of swine of the country and the second largest exporter of poultry. The state has been free of Foot and Mouth Disease without vaccination since 2007 (OIE, 2014) and has been free of Classical Swine Fever since 2015 (OIE, 2015). Its herd is approximately 4 million head, distributed throughout about 200 thousand properties. It is the fifth largest producer of milk in 
the country. It is responsible for around $8 \%$ of the national production, which is predominantly from the western region of Santa Catarina, where $70 \%$ of the milk of the State is produced (EMBRAPA, 2012). In this region the milk production, which is considered the most important social and economic regional activity, is typically implemented by small producers, with family work.

In 2012, the State published specific legislation for the eradication of bovine brucellosis that outlines the certification of infected herds as free and deployment of surveillance actions for the disease (SANTA CATARINA, 2012). Prior to the legislation, only seropositive animals were sacrificed, which was carried out for the purpose of animal movement.

A surveillance system is being deployed gradually by the Integrated Company of Agricultural Development (CIDASC), the official veterinary service of the state. A pilot project was developed for the detection of antibodies in milk and dairy products that used the milk ring test (MRT); however, the test was non-specific and produced a high number of false positive results. The adoption of serial testing, which is the MRT followed by indirect ELISA, improved the positive predictive value of the diagnostic protocol and became a promising strategy for use in a large scale (NEVES, 2015). To date, 60 infected herds have been detected by this component of the surveillance system and certified as free ones. These properties are forbidden to move animals until two negative tests of the herd are obtained. The epidemiological links are being investigated with serology to detect new infected herds following the initial one (SANTA CATARINA, 2012). The owners of seropositive animals have been indemnified by the State Fund for Animal Health (FUNDESA), which has already replaced 5,575 cattle affected by brucellosis since 2004.

The CIDASC notifies the Department of Health about the occurrence of infected herds. The Department of Health also researches human cases of infection (DIVE, 2012). In 2012, the State Protocol for Monitoring and Clinical Management of Human Brucellosis was instated and through the end of 2013, 1,487 cases were investigated and resulted in the confirmation of 29 cases of the disease, who received medical assistance and treatment provided by the State (MELO et al., 2014).

Therefore, the objective of this study was to verify the continuation of low prevalence of bovine brucellosis in Santa Catarina in order for the state to safely proceed with its implementation of strategies for disease eradication.

\section{Material and Methods}

The study was planned by veterinarians of the MAPA, the Collaborating Center in Animal Health (School of Veterinary Medicine and Animal Science at the University of São Paulo [FMVZ-USP]), and the Integrated Company of Agricultural Development of Santa Catarina (CIDASC). Fieldwork was carried out by veterinarians of CIDASC from July to November 2012.

The State was divided into regions, based on the different production systems, management practices, and type of farm. Within each region, a preestablished number of properties with reproductive activity were randomly selected (primary sampling units). This process was carried out by using the properties registry maintained by CIDASC. Within each property selected, a pre-established number of cows, aged 24 months or greater, were selected randomly (secondary sampling units).

In rural properties with more than one herd, the herd with the highest economic importance was chosen. These animals were exposed to the same management, i.e. under the same risks of exposure to infection. A randomly selected property that could not be visited, for various reasons, was replaced by a new lot.

The number of selected properties per region was estimated by the formula for simple random samples 
(THRUSFIELD, 2007). The sample size calculation considered the operating capacity of CIDASC. The parameters adopted for the calculation were as follows: confidence level of 0.95 , an estimated prevalence of 0.05 , and error of 0.025 .

The aim of planning the samples for the secondary units was estimating the minimum number of animals to be examined within each property in order to classify them as a herd that was infected or not infected with bovine brucellosis. For this task, the concept of aggregated sensitivity and specificity was used (DOHOO et al., 2003). For the purpose of the calculations, the values of 0.95 and 0.995 were adopted for the sensitivity and specificity, respectively, of the applied test protocol (FLETCHER et al., 1998). In properties with up to 99 cows, aged 24 months or greater, 10 animals were sampled and in properties with 100 or more cows, aged 24 months or greater, 15 animals were sampled. Cows in the peri-delivery period, which was approximately 15 days before and after delivery, were excluded from the selection.

The diagnostic protocol consisted of screening with the buffered acidified antigen test (Rose Bengal), followed by confirmation of the positive samples with the 2-mercaptoethanol test (2-ME), as recommended by the PNCEBT (LAGE et al., 2006). The screening tests were carried out by the CIDASC laboratories of the 2-ME test by LANAGRO - MG. Animals with inconclusive results were retested after 30 days and were classified as positive if the results remained inconclusive. The presence of at least one seropositive animal classified the property as a positive or infected herd.

The sample planning enabled us to determine the prevalence of herds and cows ( $\geq 24$ months of age) seropositive for bovine brucellosis in the state as well as the regions. The calculations for prevalence and respective confidence intervals were performed based on recommendations by Dean et al. (1994). The estimates of the prevalence of seropositive or infected herds and cows in the state and prevalence of seropositive cows within the regions were made in a weighted manner as described by Dohoo et al. (2003).

The weight of each property in calculating prevalence of positive herds in the State was given by the following equation.

$$
P_{1}=\frac{\text { Properties in the region }}{\text { Properties sampled in the region }}
$$

The weight of each animal in calculating the prevalence of infected animals in the state was determined by the following equation.

$$
\begin{gathered}
P_{2}=\frac{\text { Cows } \geq 24 \text { months on the property }}{\text { Cows } \geq 24 \text { months sampled in property }} X \\
\frac{\text { Cows } \geq 24 \text { months in the region }}{\text { Cows } \geq 24 \text { months sampled in the region }}
\end{gathered}
$$

The first term in the expression above refers to the weight of each animal in the calculation for prevalence of seropositive cows within the regions.

The estimates of prevalence ratios and their respective $95 \%$ confidence intervals were performed using the STATA13 program and the Free $\mathrm{R}$ Software. The test of two proportions was used to detect possible differences between the prevalence rates found in this study and the 2002 study.

In addition to blood sampling for serological examination in each sampled property, an epidemiological questionnaire was used to obtain information on the type of enterprise, husbandry, and sanitary practices employed. The following information was collected: type of operation, type of breeding, if artificial insemination was used, volume and characteristic of milk production, number of cows that were aged 24 months or greater, total number of bovines on the property, 
presence of other domestic species raised on the property, contact of the animals with wild species, number of abortions, destination of the abortion products, purchase and sale of animals, slaughter of animals, rental of pastures, sharing of pastures, the presence of waterholes, equipment or staff, presence of flooded areas, existence of a calving paddock, veterinary assistance, and classification of the property (classic rural, indigenous village, settlement or urban periphery).

The variables were organized on a scale of increasing risk. When necessary variables were re-categorized. The category of lower risk was considered the basis for comparison of other categories. The quantitative variables were categorized in percentiles. An exploratory analysis (univariate analysis) was performed to select those with $\mathrm{p}<0.20$ for the $\chi^{2}$ test (chi-square) or Fisher exact test and subsequent analysis by logistic regression. The calculations were performed with the freeware program, R. All the information generated by the field and laboratory work was entered into a specific database used for epidemiological analysis.

\section{Results}

The state was divided into the following five regions: 1. Serrana, which had a predominance of beef cattle; 2. Grande Florianópolis and South, which had dairy and mixed livestock farming and the production of pigs and poultry; 3. West, which had an important production of poultry and pigs intermixed with high dairy production; 4. North, which had a predominance of beef cattle; 5. Vale do Itajaí, which had dairy livestock intermixed with mixed production (Figure 1).

Figure 1. Division of the State of Santa Catarina in 5 regions with details showing the location of the State in Brazil.

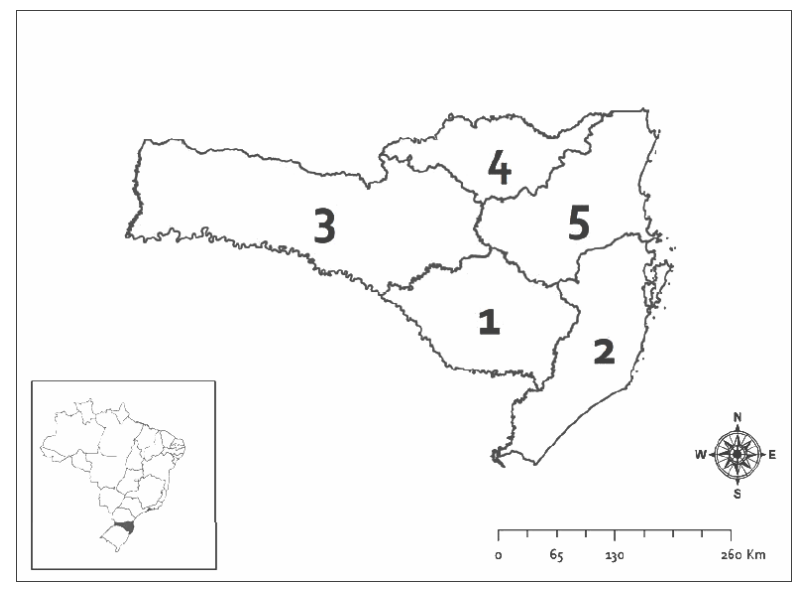

Table 1 presents a summary of the census data and studied sample. Table 2 shows the prevalence of infected herds and animals in the regions and state. Tables 3 present the comparison of the prevalence rates of this study with the 2002 study. Table 4 shows the final logistic regression model for the risk factors associating herd infection with bovine brucellosis. 
Table 1. Census and the sample data from the State of Santa Catarina, 2012.

\begin{tabular}{cccccc}
\hline Region & $\begin{array}{c}\text { Number of } \\
\text { Municipalities }\end{array}$ & $\begin{array}{c}\text { Properties with } \\
\text { reproductive } \\
\text { activity }\end{array}$ & $\begin{array}{c}\text { Sampled } \\
\text { properties }\end{array}$ & $\begin{array}{c}\text { Cows with ages } \\
\geq 24 \text { months }\end{array}$ & $\begin{array}{c}\text { Cows with ages } \\
\geq 24 \text { months } \\
\text { sampled }\end{array}$ \\
\hline 1 & 18 & 15,373 & 309 & 283,064 & 2,042 \\
2 & 57 & 40,975 & 328 & 275,401 & 1,331 \\
3 & 133 & 86,598 & 368 & $1,107,212$ & 2,646 \\
4 & 12 & 12,826 & 308 & 96,917 & 1,369 \\
5 & 75 & 43,402 & 340 & 266,871 & 1,242 \\
\hline Total & 295 & 199,174 & 1,653 & $2,029,465$ & 8,630 \\
\hline
\end{tabular}

Table 2. Prevalence of positive herds and cows for bovine brucellosis in the State of Santa Catarina, according to regions, 2012.

\begin{tabular}{lcccccc}
\hline \multirow{2}{*}{ Region } & \multicolumn{3}{c}{ Properties } & \multicolumn{3}{c}{ Cows with ages $\geq 24$ months } \\
\cline { 2 - 6 } & $\begin{array}{c}\text { Positive/ } \\
\text { examined }\end{array}$ & Prevalence (\%) & $95 \%$ CI (\%) & $\begin{array}{c}\text { Positive/ } \\
\text { examined }\end{array}$ & Prevalence (\%) & $95 \%$ CI (\%) \\
\hline 1 & $0 / 309$ & 0.32 & $0-0.96^{*}$ & $0 / 2,042$ & 0 & - \\
2 & $7 / 328$ & 2.13 & $0.86-4.35$ & $10 / 1,331$ & 1.02 & $0.28-2.57$ \\
3 & $4 / 368$ & 1.09 & $0.30-2.76$ & $6 / 2,646$ & 1.97 & $0.11-8.84$ \\
4 & $0 / 308$ & 0.33 & $0-0.97^{*}$ & $0 / 1,369$ & 0 & - \\
5 & $0 / 304$ & 0.29 & $0-0.88^{*}$ & $0 / 1,242$ & 0 & - \\
\hline Total & $11 / 1,653$ & 0.91 & $0.30-2.11$ & $16 / 8,630$ & 1.21 & $0.09-4.97$ \\
\hline
\end{tabular}

* calculated using the method of Monte Carlo and beta distribution.

Table 3. Comparison of the prevalence of positive herds for bovine brucellosis between the present study (2012) and the study performed in 2002 in Santa Catarina.

\begin{tabular}{cccccccc}
\hline \multirow{2}{*}{ Region } & \multicolumn{9}{c}{2002} & \multicolumn{3}{c}{2012} & \\
\cline { 2 - 6 } & $\begin{array}{c}\text { Properties } \\
\text { Positive / } \\
\text { examined }\end{array}$ & $\begin{array}{c}\text { Prevalence } \\
(\%)\end{array}$ & $95 \%$ CI (\%) & $\begin{array}{c}\text { Properties } \\
\text { positive / } \\
\text { examined }\end{array}$ & $\begin{array}{c}\text { Prevalence } \\
(\%)\end{array}$ & $95 \%$ CI (\%) & p value \\
\hline 1 & $0 / 299$ & 0.33 & $0-0.99$ & $0 / 309$ & 0.32 & $0-0.96$ & $>0.05$ \\
2 & $0 / 298$ & 0.33 & $0-1.00$ & $7 / 328$ & 2.13 & $0.86-4.35$ & 0.03 \\
3 & $0 / 396$ & 0.25 & $0-0.75$ & $4 / 368$ & 1.09 & $0.30-2.76$ & $>0.05$ \\
4 & $1 / 297$ & 0.66 & $0-1.84$ & $0 / 308$ & 0.33 & $0-0.97$ & $>0.05$ \\
5 & $0 / 296$ & 0.33 & $0-1.00$ & $0 / 304$ & 0.29 & $0-0.88$ & $>0.05$ \\
\hline Total & $1 / 1,586$ & 0.32 & $0.10-0.69$ & $11 / 1,653$ & 0.91 & $0.30-2.11$ & $>0.05$ \\
\hline
\end{tabular}


Table 4. Multiple logistic regression analysis and the risk factors associated with bovine brucellosis in the State of Santa Catarina, 2012.

\begin{tabular}{lcc}
\hline \multicolumn{1}{c}{ Variable } & OR & CI (95\%) \\
\hline $\begin{array}{l}\text { The number of cows aged } \geq 24 \text { months } \\
<11\end{array}$ & & \\
$\geq 12^{*}$ & 7.47 & $2.14-34.34$ \\
Presence of either flooded areas & & \\
Not & 5.68 & $1.62-26.13$ \\
Yes & & \\
\hline
\end{tabular}

* third quartile.

\section{Discussion}

In relation to the study performed in 2002 (SIKUSAWA, 2009), an increased prevalence of infected herds was only detected in region 2 (Table 3). However, the prevalence of infected herds in the state is still very low $(0.91 \%$, Table 2$)$, which reaffirms that the state should maintain the prohibition of vaccination with B19 and proceed with the eradication strategies, based on the structure of the surveillance system for detection and certification of residual affected herds as free ones.

To date, with regard to the detection of infected herds, the state has gained important experience with the assessment of antibodies in the milk and dairy products, the notification of positive serological tests that were carried out for the purpose of animal movement, and is starting to perform an investigation of epidemiological links upstream and downstream to the infected herds. However, it would be interesting to add a third component to this system and include the beef properties and those who sell milk informally. One strategy to be considered is investigating the serology of culled cows at the end of their reproductive life, which can be implemented in the slaughterhouse.

The components of infected herds detection systems would include the notification of tests for the transit of animals, the assessment of antibodies in milk, and the serology of slaughtered cows, complemented by research upstream and downstream from all the infected herds identified by the three components. One must keep in mind that surveillance systems are complex structures and should include management by permanent assessment tools. This set would represent an excellent point of departure, which could be improved as the results are obtained and the evaluations are carried out. If successful, the model developed by the State of Santa Catarina would serve as an example for the rest of the country.

The study of risk factors indicates that the number of cows equal to or greater than 12 and the presence of flooded areas in the property are associated with brucellosis infection in Santa Catarina (Table 4). The association between the herd size and brucellosis has already been reported by several international authors (KELLAR et al., 1976; NICOLETTI, 1980; SALMAN; MEYER, 1984). In Brazil, this association was also observed in the states of Mato Grosso, Rio de Janeiro, Sergipe, Tocantins, São Paulo and Mato Grosso do Sul (NEGREIROS et al., 2009; KLEIN-GUNNEWIEK et al., 2009 SILVA et al., 2009;; OGATA et al., 2009; DIAS et al., 2009b; CHATE et al., 2009). Particular characteristics of larger herds facilitate the transmission of brucellosis, especially the increased need for replacement of animals, the greater difficulty in implementing measures to control the disease, and the dynamics of brucellosis itself (CRAWFORD et al., 1990). Christie (1969) observed that an increase of the herd size results in an increased probability of occurrence and persistence of the infection and difficulty to eradicate brucellosis. Therefore, the larger the size of the herd, the greater the risk of 
introducing brucellosis as well as the probability of its spreading within the herd.

The survival of Brucella abortus in the environment is enhanced by the presence of humidity. The greater the survival rate in a larger environment, the higher the probability of this agent infecting a new susceptible animal (PAULIN; FERREIRA NETO, 2003). Thus, the presence of flooded areas in the property can promote the dissemination of the disease. This variable was found to be associated with herds infected with bovine brucellosis in Brazilian Northeast, Bahia, Pernambuco and Maranhão, (ALVES et al., 2009; ALMEIDA et al., 2016; BORBA et al., 2013). However, it is worth mentioning that this factor is related more to the maintenance of the disease within an infected property than to the form of transmission between herds (CRAWFORD et al., 1990).

\section{Conclusions}

The State of Santa Catarina continues with a very low prevalence of bovine brucellosis and consequently vaccination with the B19 vaccine should remain prohibited. The State should prioritize the implementation of eradication strategies that are based on the structure of the surveillance system for detection and eliminate infected herds, supported by an effective compensation fund for the replacement of animals with positive serological test results. Additionally, the State should make significant efforts to educate and supervise producers to test breeding animals for brucellosis before introducing them in their properties.

\section{Acknowledgements}

We would like to acknowledge the following: the joint efforts of the veterinary team of CIDASC and farmers of Santa Catarina; the financing of the MAPA, World Bank and CIDASC, Fapesp and $\mathrm{CNPq}$; the team of epidemiology of Animal Health
Department, Claudia Scotti Ducioni Matos, and Renata Gonçalves Martins Medtisch.

\section{References}

ADONE, R.; PASQUALI, P. Epidemiosurveillance of brucellosis. Revue Scientifique et Technique de l'OIE, Paris, v. 32, n. 1, p. 199-205, 2013.

ALMEIDA, E. C.; FREITAS, A. A.; PONTUAL, K. A. Q.; SOUZA, M. M. A.; AMAKU, M.; DIAS, R. A.; FERREIRA, F.; TELLES, E. O.; HEINEMANN, M. B.; GONÇALVES, V. S. P.; EVÊNCIO NETO, J.; MARVULO, M. F. V.; GRISI-FILHO, J. H. H.; FERREIRA NETO, J. S.; SILVA, J. C. R. Prevalence and associated risk factors for bovine brucellosis in the state of Pernambuco, Brazil. Semina: Ciências Agrárias, Londrina, v. 37, n. 5, p. 3413-3424, 2016. Suplemento 2.

ALVES, A. J. S.; GONÇALVES, V. P. S.; FIGUEIREDO, V. C. F.; LÔBO, J. R.; BAHIENSE, L.; AMAKU, M.; FERNANDO, F.; FERREIRA NETO, J. S.; DIAS, R. A. Situação epidemiológica da brucelose bovina no Estado da Bahia. Arquivo Brasileiro de Medicina Veterinária e Zootecnia, Belo Horizonte, v. 61, p. 6-13, 2009. Suplemento 1.

ANZAI, E. K.; COSTA, D.; SAID, A. L. P. R.; GRISI-FILHO, J. H. H.; AMAKU, M.; DIAS, R. A.; FERREIRA, F.; GALVIS, J. O. A.; GONÇALVES, V. S. P.; HEINEMANN, M. B.; TELLES, E. O.; FERREIRA NETO, J. S. An update on the epidemiological situation of bovine brucellosis in the state of Espírito Santo, Brazil. Semina: Ciências Agrárias, Londrina, v. 37, n. 5, p. 3437-3448, 2016. Suplemento 2.

AZEVEDO, S. S.; FERREIRA NETO, J. S.; DIAS, R. A.; FERREIRA, F.; AMAKU, M.; FIGUEIREDO, V. C. F.; LÔBO, J. R.; GONÇALVES, V. S. P.; SOUZA, A. C.; VASCONCELLOS, S. A. Situação epidemiológica da brucelose bovina no Estado do Espírito Santo. Arquivo Brasileiro de Medicina Veterinária e Zootecnia, Belo Horizonte, v. 61, p. 19-26, 2009. Suplemento 1.

BARDDAL, J. E. I.; SANTOS, J. C. Q.; LOPES, I. F.; FERREIRA NETO, J. S.; FERREIRA, F.; AMAKU, M.; DIAS, R. A.; TELLES, E. O.; GRISI-FILHO, J. H. H.; HEINEMANN, M. B.; GONÇALVES, V. S. P.; AGUIAR, D. M. Effect of vaccination in lowering the prevalence of bovine brucellosis in the state of Mato Grosso, Brazil. Semina: Ciências Agrárias, Londrina, v. 37, n. 5, p. 3479-3492, 2016. Suplemento 2.

BORBA, M. R.; STEVENSON, M. A.; GONÇALVES, V. S. P.; FERREIRA NETO, J. S.; FERREIRA, F.; AMAKU, M.; TELLES, E. O.; SANTANA, S. S.; FERREIRA, J. 
C. A.; LÔBO, J. R.; FIGUEIREDO, V. C. F.; DIAS, R. A. Prevalence and risk-mapping of bovine brucellosis in Maranhão State, Brazil. Preventive Veterinary Medicine, v. 110, n. 2, p. 169-176, 2013.

CHATE, S. C.; DIAS, R. A.; AMAKU, M.; FERREIRA, F.; MORAES, G. M.; COSTA NETO, A. A.; MONTEIRO, L. A. R. C.; LÔBO, J. R.; FIGUEIREDO, V. C. F.; GONÇALVES, V. S. P.; FERREIRA NETO, J. S. Situação epidemiológica da brucelose bovina no Estado do Mato Grosso do Sul. Arquivo Brasileiro de Medicina Veterinária e Zootecnia, Belo Horizonte, v. 61, p. 46-55, 2009. Suplemento 1.

CHRISTIE, T. E. Eradication of brucellosis in Northern Ireland: field problems and experiences. Veterinary Record, v. 85, p. 268-269, 1969.

CLEMENTINO, I. J.; DIAS, R. A.; AMAKU, M.; FERREIRA, F.; TELLES, E. O.; HEINEMANN, M. B.; GONÇALVES, V. S. P.; GRISI-FILHO, J. H. H.; FERREIRA NETO, J. S.; ALVES, C. J.; SANTOS, C. S. A. B.; AZEVEDO, S. S. Epidemiological situation of bovine brucellosis in the state of Paraiba, Brazil. Semina: Ciências Agrárias, Londrina, v. 37, n. 5, p. 3403-3412, 2016. Suplemento 2.

CRAWFORD, R. P.; HUBER, J. D.; ADAMS, B. S. Epidemiology and surveillance. In: NIELSEN, K.; DUNCAN, J. R. (Ed.). Animal brucellosis. Boca Raton: CRC Press, 1990. p. 131-151.

DEAN，A. G.; DEAN，J. A; COULOMBIER，D.; BRENDEL, K. A.; SMITH, D. C.; BURTON, A. H.; DICKER, R. C.; SULLIVAN, K.; FAGAN, R. F.; ARNER, T. G. Epi Info 6: a word processing database, and statistics program for epidemiology on microcomputers. Atlanta: Center for Diseases Control and Prevention, 1994. $601 \mathrm{p}$.

DIAS, J. A.; MÜLLER, E. E.; DIAS, R. A.; FREITAS, J. C.; AMAKU, M.; FERREIRA, F.; SILVA, M. C. P.; LÔBO, J. R.; FIGUEIREDO, V. C. F.; GONÇALVES, V. S. P.; FERREIRA NETO, J. S. Situação epidemiológica da brucelose bovina no Estado do Paraná. Arquivo Brasileiro de Medicina Veterinária e Zootecnia, Belo Horizonte, v. 61, p. 66-76, 2009a. Suplemento 1.

DIAS, R. A.; BELCHIOR, A. P. C.; FERREIRA, R. S.; GONÇALVES, R. C.; AGUIAR, R. S. C. B.; SOUSA, P. R.; SANTOS, A. M. A.; AMAKU, M.; FERREIRA, F.; TELLES, E. O.; GRISI-FILHO, J. H. H.; HEINEMANN, M. B.; GONÇALVES, V. S. P.; FERREIRA NETO, J. S. Controlling bovine brucellosis in the State of São Paulo, Brazil: results of ten years of vaccination program. Semina: Ciências Agrárias, Londrina, v. 37, n. 5, p. 3505-3518, 2016. Suplemento 2.
DIAS, R. A.; GONÇALVES, V. S. P.; FIGUEIREDO, V. C. F.; LÔBO, J. R.; LIMA, Z. M. B.; PAULIN, L. M. S.; GUNNEWIEK, M. F. K.; AMAKU, M.; FERREIRA NETO, J. S.; FERREIRA, F. Situação epidemiológica da brucelose bovina no Estado de São Paulo. Arquivo Brasileiro de Medicina Veterinária e Zootecnia, Belo Horizonte, v. 61, p. 118-125, 2009b. Suplemento 1.

DÍAZ APARICIO, E. Epidemiology of brucellosis in domestic animals caused by Brucella melitensis, Brucella suis and Brucella abortus. Revue Scientifique et Technique de l'OIE, Paris, v. 32, n. 1, p. 53-60, 2013.

DIRETORIA DE VIGILÂNCIA EPIDEMIOLÓGICA - DIVE. Protocolo Estadual de Vigilância e Manejo Clínico da Brucelose Humana. Florianópolis: Estado de Santa Catarina, 2012. Disponível em: <http://www.dive. sc.gov.br/conteudos/zoonoses/publicacoes/Protocolo Clinico_de_Brucelose_Humana.pdf $>$. Acesso em: $2 \overline{6}$ set. 2016.

DOHOO, I.; MARTIN, W.; STRYHN, H. Methods in epidemiologic research. Charlottetown: University of Prince Edward Island, 2003.

EMPRESA BRASILEIRA DE PESQUISA AGROPECUÁRIA - EMBRAPA. Ranking da produção de leite por Estado, 2010-2011. Centro Nacional de Pesquisa de Gado de Leite. Coronel Pacheco: Embrapa Gado de Leite, 2012. Disponível em: <http://www.cnpgl. embrapa.br/nova/informacoes/estatisticas/producao/ tabela0240.php>. Acesso em: 26 set. 2016.

FLETCHER, R. H.; FLETCHER, S. W.; WAGNER, E. H. Clinical epidemiology: the essentials. $2^{\text {th }}$ ed. Baltimore: Williams \& Wilkins, 1998.

GONÇALVES, V. S. P.; DELPHINO, M. K. V. C.; DIAS, R. A.; FERREIRA, F.; AMAKU, M.; FERREIRA NETO, J. S.; PORTO, T. B.; ALVES, C. M.; FIGUEIREDO, V. C. F.; LÔBO, J. R. Situação epidemiológica da brucelose bovina no Estado de Minas Gerais. Arquivo Brasileiro de Medicina Veterinária e Zootecnia, Belo Horizonte, v. 61, p. 35-45, 2009a. Suplemento 1.

GONÇALVES, V. S. P.; RIBEIRO, L. A.; CALDAS, R. A.; FRANCISCO, P. F. C.; DIAS, R. A.; FERREIRA, F.; AMAKU, M.; FERREIRA NETO, J. S.; FIGUEIREDO, V. C. F.; LÔBO, J. R.; BORGES, J. R. J. Situação epidemiológica da brucelose bovina no Distrito Federal. Arquivo Brasileiro de Medicina Veterinária e Zootecnia, Belo Horizonte, v. 61, p. 14-18, 2009b. Suplemento 1.

INLAMEA, O. F.; ROCHA, A. B.; FERREIRA, F.; GRISI-FILHO, J. H. H.; HEINEMANN, M. B.; DIAS, R. A.; TELLES, E. O.; GONÇALVES, V. S. P.; AMAKU, M.; FERREIRA NETO, J. S. Effect of vaccination in lowering bovine brucellosis in the state of Rondônia, 
Brazil. Semina: Ciências Agrárias, Londrina, v. 37, n. 5, p. 3493-3506, 2016. Suplemento 2.

KELLAR, J.; MARRA, R.; MARTIN, W. Brucellosis in Ontario: a case control study. Canadian Journal of Comparative Medicine, cidade, v. 40, n. 2, p.119-128, 1976.

KLEIN-GUNNEWIEK, M. F. C.; AMAKU, M.; DIAS, R. A.; FERREIRA, F.; GITTI, C. B.; PEREIRA, L. A.; FIGUEIREDO, V. C. F.; LOBO, J. R.; GONÇALVES, V. S. P.; FERREIRA NETO, J. S. Situação epidemiológica da brucelose bovina no Estado do Rio de Janeiro. Arquivo Brasileiro de Medicina Veterinária e Zootecnia, Belo Horizonte, v. 61, p. 77-84, 2009. Suplemento 1.

LAGE, A. P.; ROXO, E.; MÜLLER, E.; POESTER, F.; CAVAllÉRO, J. C. M.; FERREIRA NETO, J. S.; MOTA, P. M. P. C.; GONÇALVES, V. S. P. Programa nacional de controle e erradicação da Brucelose e da tuberculose animal (PNCEBT). Brasília: Ministério da Agricultura, Pecuária e Abastecimento. 2006. 184 p. (Manual Técnico). Disponível em: <http://www. agricultura.gov.br>. Acesso em: 26 set. 2016.

LEAL FILHO, J. M.; BOTTENE, I. F. N.; MONTEIRO, L. A. R. C.; PELLEGRIN, A. O.; GONÇALVES, V. S. P.; FERREIRA, F.; DIAS, R. A.; AMAKU, M.; TELLES, E. O.; GRISI-FILHO, J. H. H.; HEINEMANN, M. B.; FERREIRA NETO, J. S. Control of bovine brucellosis from 1998 to 2009 in the state of Mato Grosso do Sul, Brazil. Semina: Ciências Agrárias, Londrina, v. 37, n. 5, p. 3467-3478, 2016. Suplemento 2.

MARVULO, M. F. V.; FERREIRA, F.; DIAS, R. A.; AMAKU, M.; GROFF, A. C. M.; GONÇALVES, V. S. P.; FIGUEIREDO, V. C. F.; LÔBO, J. R.; FERREIRA NETO, J. S. Situação epidemiológica da brucelose bovina no Estado do Rio Grande do Sul. Arquivo Brasileiro de Medicina Veterinária e Zootecnia, Belo Horizonte, v. 61, p. 93-102, 2009. Suplemento 1.

MELO, F. R.; FOLSTER, I. C.; GHAZZI, M. S.; ZECCER, S. Perfil da brucelose humana em Santa Catarina. Informativo Epidemiológico Barriga Verde, Florianópolis, Ano 12, n. 1, p. 4-6, 2014.

NEGREIROS, R. L.; DIAS, R. A.; FERREIRA, F.; FERREIRA NETO, J. S.; GONÇALVES, V. S. P.; SILVA, M. C. P.; FIGUEIREDO, V. C. F.; LÔBO, J. R.; FREITAS, J.; AMAKU, M. Situação epidemiológica da brucelose bovina no Estado do Mato Grosso. Arquivo Brasileiro de Medicina Veterinária e Zootecnia, Belo Horizonte, v. 61, p. 56-65, 2009. Suplemento 1.

NEVES, M. V. O. Relatórios de atividades do programa SCRural - projeto piloto de erradicação da Brucelose Bovina. Florianópolis: CIDASC, 2015. (Comunicação oral).
NICOLETTI, P. The epidemiology of bovine brucellosis. Advances in Veterinary Science and Comparative Medicine, v. 24, p. 69-98, 1980.

OGATA, R. A.; GONÇALVES, V. S. P.; FIGUEIREDO, V. C. F.; LÔBO, J. R.; RODRIGUES, A. L.; AMAKU, M.; FERREIRA, F.; FERREIRA NETO, J. S.; DIAS, R. A. Situação epidemiológica da brucelose bovina no Estado do Tocantins. Arquivo Brasileiro de Medicina Veterinária e Zootecnia, Belo Horizonte, v. 61, p. 126134, 2009. Suplemento 1.

OLIVEIRA, L. F.; DORNELES, E. M. S.; MOTA, A. L. A. A.; GONÇALVES, V. S. P.; FERREIRA NETO, J. S.; FERREIRA, F.; DIAS, R. A.; TELLES, E. O.; GRISIFILHO, J. H. H.; HEINEMANN, M. B.; AMAKU, M.; LAGE, A. P. Seroprevalence and risk factors for bovine brucellosis in the State of Minas Gerais, Brazil. Semina: Ciências Agrárias, Londrina, v. 37, n. 5, p. 3449-3446, 2016. Suplemento 2.

PAULIN, L. M.; FERREIRA NETO, J. S. O combate à brucelose bovina: situação brasileira. Jaboticabal: Fundação de Estudos e Pesquisas em Agronomia, Medicina Veterinária e Zootecnia, 2003. 154 p.

ROCHA, W. V.; GONÇALVES, V. S. P.; COELHO, C. G. N. F. L.; BRITO, W. M. E. D.; DIAS, R. A.; DELPHINO, M. K. V. C.; FERREIRA, F.; AMAKU, M.; FERREIRA NETO, J. S.; FIGUEIREDO, V. C. F.; LÔBO, J. R.; BRITO, L. A. B. Situação epidemiológica da brucelose bovina no Estado de Goiás. Arquivo Brasileiro de Medicina Veterinária e Zootecnia, Belo Horizonte, v. 61, p. 27-34, 2009. Suplemento 1.

SALMAN, M. D.; MEYER, M. E. Epidemiology of bovine brucellosis in the Mexicali Valley, Mexico: literature review of disease-associated factors. Americam Journal Veterinary Research, v. 45, n. 8, p. 1557-1560, 1984.

SANTA CATARINA - Estado. Secretaria de Estado da Agricultura e da Pesca. Portaria SAR n ${ }^{\circ}$ 17/2012, de 20/07/2012. Diário Oficial [do] Estado de Santa Catarina. Florianópolis, 24 jul. 2012. ed. 19.380, p. 3.

SANTOS, R. L.; MARTINS, T. M.; BORGES, A. M.; PAIXÃO, T. A. Economic losses due to brucellosis in Brazil. Pesquisa Veterinária Brasileira, Seropédica, v. 33, n. 6, p. 759-764, 2013.

SIKUSAWA, S.; AMAKU, M.; DIAS, R. A.; FERREIRA NETO, J. S.; MARTINS, C.; GONÇALVES, V. S. P.; FIGUEIREDO, V. C. F.; LÔBO, J. R.; FERREIRA, F. Situação epidemiológica da brucelose bovina no Estado de Santa Catarina. Arquivo Brasileiro de Medicina Veterinária e Zootecnia, Belo Horizonte, v. 61, n. 1, p. 103-108, 2009. 
SILVA, N. S.; GROFF, A. C. M.; VIDOR, A. C. M.; GRISI-FILHO, J. H. H.; HEINEMANN, M. B.; DIAS, R. A.; TELLES, E. O.; GONÇALVES, V. S. P.; AMAKU, M.; FERREIRA, F.; FERREIRA NETO, J. S. Epidemiological situation of brucellosis after implementation of the vaccination program in Rio Grande do Sul State, Brazil. Semina: Ciências Agrárias, Londrina, v. 37, n. 5, p. 3519-3530, 2016. Suplemento 2.

SILVA, V.G.S.O.;DIAS, R.A.;FERREIRA,F.;AMAKU, M.; COSTA, E. L. S.; LÔBO, J. R.; FIGUEIREDO, V. C. F.; GONÇALVES, V. S. P.; FERREIRA NETO, J. S. Situação epidemiológica da brucelose bovina no Estado de Sergipe. Arquivo Brasileiro de Medicina Veterinária e Zootecnia, Belo Horizonte, v. 61, p. 109-117, 2009. Suplemento 1.

THRUSFIELD, M. Veterinary epidemiology. $3^{\text {th }}$ ed. Oxford: Blackwell Science, 2007.
VILLAR, K. S.; AMAKU, M.; DIAS, R. A.; FERREIRA NETO, J. S.; BENITEZ, F.; GONÇALVES, V. S. P.; FIGUEIREDO, V. C. F.; LÔBO, J. R.; FERREIRA, F. Situação epidemiológica da brucelose bovina no Estado de Rondônia. Arquivo Brasileiro de Medicina Veterinária e Zootecnia, Belo Horizonte, v. 61, p. 85-92, 2009. Suplemento 1.

WORLD ORGANISATION FOR ANIMAL HEALTH - OIE. List of CSF free member counties Paris: OIE, 2015. Available at: http://www.oie.int/animal-health-inthe-world/official-disease-status/classical-swine-fever/ list-of-csf-free-member-countries/.>. Acesso em: 26 set. 2016.

. List of FMD free members countries - according to resolution $n^{\circ} 15-82^{\text {nd }}$ General Session May 2014. Paris: OIE, 2014. Available at: <http://www.oie.int/en/ animal-health-in-the-world/official-disease-status/fmd/ list-of-fmd-free-members/\#c10691>. Acesso em: 26 set. 2016. 
